\section{EMBRYRIDDLE}

Aeronautical University

SCHOLARLY COMMONS
Journal of Aviation/Aerospace

Education \& Research

Volume 26

Number 2 JAAER 2017

Article 2

2017

\title{
Competency-Based Training in Aviation: The Impact on Flight Attendant Performance and Passenger Satisfaction
}

Latoya Gibbs

Oklahoma State University, ladegibbs@hotmail.com

Lisa Slevitch

Oklahoma State University

Isaac Washburn

Oklahoma State University

Follow this and additional works at: https://commons.erau.edu/jaaer

Part of the Curriculum and Instruction Commons, Hospitality Administration and Management Commons, and the Tourism and Travel Commons

\section{Scholarly Commons Citation}

Gibbs, L., Slevitch, L., \& Washburn, I. (2017). Competency-Based Training in Aviation: The Impact on Flight Attendant Performance and Passenger Satisfaction. Journal of Aviation/Aerospace Education \& Research, 26(2). https://doi.org/10.15394/jaaer.2017.1716

This Article is brought to you for free and open access by the Journals at Scholarly Commons. It has been accepted for inclusion in Journal of Aviation/Aerospace Education \& Research by an authorized administrator of Scholarly Commons. For more information, please contact commons@erau.edu. 


\section{Introduction}

Commercial aircraft design, operation and manufacturing has seen substantial technological developments over the previous decades producing a different generation of aircraft. As a result, the International Civil Aviation Organization (ICAO, 2010) has implemented a new competency-based training (CBT) methodology to meet this emerging environment. To date, ICAO $(2010,2014)$ has developed CBT guidance for dangerous goods state employees, designated medical examiners, flight procedure designers, and CBT has been adapted for air traffic controllers, aircraft maintenance personnel and is currently in place for commercial pilot license training (International Air Transport Association [IATA], 2015).

In 2014, ICAO (2014) recommended CBT for flight attendant safety and security training, primarily to increase on-the-job performance, safety proficiency and also to institute an international baseline for flight attendant competencies. While safety and security training are mandated by ICAO, cabin passenger service training, one of three categories (safety, security and service) of cabin crew responsibilities (Damos, Boyett, \& Gibbs, 2013; ICAO, 2003) is determined by the airlines' management. Although there are no mandated regulations for customer service training, including $\mathrm{CBT}$ as a standard is relevant to increase flight attendant performance, service proficiency, and to appropriately balance cabin service with safety-related duties which ultimately leads to passenger satisfaction.

Empirical research indicates that whereas passengers rank airlines using multiple criteria such as safety, price, loyalty, schedule, national carrier status, baggage allowance, and on-time performance (American Customer Satisfaction Index [ACSI], 2012; Bowen \& Headley, 2016; Curtis, Rhoades, \& Waguespack, 2012), among other factors, the most important principle for competitiveness, and survival among airlines, is delivering high-quality service along with safety 
and security to passengers. Some researchers purport that the major concerns of the aviation industry are safety, security, and expectations of service excellence from the traveling public (Appelbaum \& Fewster, 2004; Hochschild, 1983).

According to the United Nations World Tourism Organization (UNWTO, 2017), over one billion tourists traveled the globe in 2016. Nevertheless, aviation today faces a series of pressing challenges. In spite of this increase of travelers, airlines are faced with declining levels of passenger satisfaction (ACSI, 2012), which is defined as "a judgment made on the basis of a specific service encounter" (Archana \& Subha, 2012, p. 51) or "a feeling based on the service experience of a passenger's most recent flight" (Park, 2007, p. 239). In addition, the current worldwide economic environment as well as increased competition has adversely impacted the financial performance of airlines and many have restructured to cut costs, merged or ceased operations. Low passenger satisfaction coupled with increased competition poses a challenge for airlines as a number of researchers have suggested a significant association between satisfaction and profitability (Fornell, Morgeson III, \& Hult, 2016; Heskett, Jones, Loveman, Sasser, \& Schlesinger, 1994).

While it is necessary to employ cost minimization strategies for survival, it is critical to understand that service companies like airlines, create value through performances (Berry, 1999) and effective performances are achieved through comprehensive training methods. Frontline service employees like flight attendants create a critical impression of the service by their behaviors and attitudes, which can significantly affect customer perceptions and satisfaction. Nevertheless, many unknowns exist about what creates such impression and how it can be improved. In particular, no study has investigated the effects of CBT on flight attendants' performance and consequently passengers' satisfaction. 
The primary objective of this study is to investigate the effectiveness of CBT to improve flight attendants' service performance and passenger satisfaction with the in-flight service. Specifically, we explore the following research questions: (1) Is there a positive association between flight attendants' performance and customer satisfaction? (2) Is there an increase in flight attendants' performance scores after CBT? and (3) Is there an increase in passenger satisfaction scores after CBT? In the following sections, we briefly review the literature, discuss our research hypothesis and methods, summarize our findings, and conclude with contributions, limitations, and recommendations for future research.

\section{Literature Review}

The commercial airline industry is highly competitive and researchers have highlighted that customer contact employees are the key differentiators of passenger satisfaction through the quality service they provide (Babbar \& Koufteros, 2008). Where an airline may be able to match prices, offer the same variety of meals, schedule flexibility or loyalty program as competitors, the most important principle for survival is the delivery of quality service. Dolnicar, Grabler, Grün, and Kulnig (2011), identified differences in drivers of airline loyalty and found that loyalty programs are associated with airline choice, more so for business and frequent travelers. However, among occasional users such as casual and leisure travelers, loyalty programs offered less advantage. Other research has also shown that service quality can directly or indirectly influence the behavioral intentions of customers (Zeithaml, Berry, \& Parasuraman, 1996). Ultimately, it is the flight attendants' performance based on the acquired knowledge and skill garnered through training that result in passenger satisfaction. These employees are the touch point to the business and in today's increasingly competitive globalized environment, are central in the shaping of the customer's positive perception and satisfaction. 
Passengers tend to evaluate airlines based on their degree of satisfaction with the in-flight service (Park, Robertson, \& Wu, 2004). Therefore, the significance of in-flight service training becomes critical as empirical evidence shows that the flight attendant is the airline employee that interfaces the most and for the longest period of time with the customer. Even though other factors that affect passenger satisfaction may at times be beyond the control of the airline (such as weather delays), some factors can be controlled and improved; for example, training.

To date, the advantages and importance of training for job and organizational performance have been extensively documented and researchers have found positive associations between training and several job factors (Aguinis \& Kraiger, 2009; Bartel, 1994; Batt, 1999; Curtis et al., 2012). Bartel (1994) and Batt (1999) found that employee productivity, service quality and customer satisfaction increased the more training employees received. Curtis et al. (2012) found that employee training was associated with profitability. Subsequently, some airlines, like Lufthansa, are actively conducting competency-based training programs (Kim \& Park, 2014) to ensure that flight attendants have the requisite knowledge and skill because organizational success is contingent on the service provided by the cabin crew.

Concern for quality is common across all industries, but it is more important for industries such as aviation where quality occurs during the delivery of the service or product. CBT can be used as a tool to increase the employee's knowledge, skills, and attitudes that correlate with performance on-the-job and consequently improve employee service performance, passenger satisfaction and ultimately the organization's performance (Wu, 2013). Consequently, it is important to understand what constitutes CBT in order to explore its possible effects on flight attendant performance. 


\section{Competency-Based Training (CBT)}

Even though the literature is replete with information about competency, there has been no standard definition but a multiplicity of terms and spellings used interchangeably, which may lead to confusion about the concept. In order to define CBT, a distinction should be made for these terms used interchangeably in the literature. In the United States, where the emphasis is on potential proficiency, the term "competency" plural "competencies" is defined by Boyatzis (1982) as "the underlying characteristics of a person that leads to or causes effective and outstanding performance” (p. 21). The United Kingdom and Australian models define "competence" and the plural "competences" as a range of standards for occupational performance or profession derived from analysis of job functions in the workplace. One viewpoint refers to individual behavior in the organizational context, germane to performance on-the-job (performance-based). While the second viewpoint, refers to classifiable (attributebased) features of people who perform their job efficiently (Robotham, 2003). However, in this study, similar to Klendauer, Berkovich, Gelvin, Leimeister, and Krcmar (2012), we adopted a performance-based perspective and used the ICAO (2014) definition, a combination of skills, knowledge and attitudes required to perform a task to the prescribed standard. CBT is based on the participant's ability to demonstrate knowledge, skills, and attitudes, under certain conditions that correlate with individual performance on-the-job rather than achievement relative to others, measured against benchmarked industry standards of performance.

Although there is substantial support for CBT (Foyster, 1990), it is not without opponents (Kosbab, 2003). In endorsing CBT, Foyster (1990) posits that this method usually works more effectively than traditional forms of training to increase employee skill levels and productivity. In contrast, Hyland (1994, p. 35), argues that CBT is 'theoretically and methodologically 
vacuous'. Other opponents such as Jackson (1994) contend that after many decades of theoretical and empirical research in the disciplines of education, sociology, psychology among others, competence-based education and training has not and will not increase learning. Despite such contending views, advocates for flight attendant CBT (Kearns, Mavin, \& Hodge, 2016; ICAO, 2014), argue that the approach offers a range of benefits including but not limited to reduced but more efficient training time, requires learners to perform task in a job-like setting; provides self-paced learning, increases on-the-job performance, and competencies acquired are observable, measurable and transferable.

\section{Research Hypotheses}

Scholarly attention has been directed to improving flight attendant performance. Kim and Park (2014) in their seminal study, comprehensively sought to identify the job competencies required of airline cabin crews. Even though there has been considerable research (Curtis et al., 2012; Saha \& Theingi, 2009) conducted on the relationship between employee performance and customer satisfaction, no study has probed the relationship between CBT, flight attendant performance, and customer satisfaction. Therefore, this study seeks to contribute to the body of existing knowledge in the area and fill in the existing gap in the research. The following research hypotheses were proposed:

$\mathrm{H}_{1:}$ There is a positive association between flight attendants' performance and customer satisfaction pre-CBT.

$\mathrm{H}_{2}$ : There is a positive association between flight attendants' performance and customer satisfaction post-CBT.

$\mathrm{H}_{3}$ : Flight attendants' performance scores post-CBT will be higher than flight attendants' performance scores pre-CBT. 
$\mathrm{H}_{4:}$ Customer satisfaction scores post-CBT will be higher than customer satisfaction scores pre-CBT.

\section{Methods}

The purpose of this study was to investigate the effectiveness of the CBT for enhancing flight attendants' performance and passenger satisfaction. The research also sought to examine the relationship between flight attendant performance and customer satisfaction. Using the Caribbean Community's (CARICOM) aviation framework as a point of reference, data was collected in-flight from passengers of a major airline headquartered in the region. The airline operates to destinations in the Caribbean, North and South America using a fleet of 13 aircraft from two separate base locations, and employs 530 flight attendants (405 flight attendants are based at location A and 125 flight attendants are based at location B).

In keeping with the airlines' commitment to provide professional growth to employees and to provide the highest standards of service to passengers, all 109 active duty flight attendants operating solely from location B (consisting of one aircraft type) were required to attend a two day competence-based leadership workshop. The training was a new initiative by the airline in partnership with the National Training Agency (NTA) and not part of its regular training/evaluation exercise. As a statutory organization, the NTA is internationally accredited to train, assess and certify employees in accordance with standards benchmarked internationally. The flight attendants were trained in four nationally-recognized competency units: managing stress, dealing with conflict situations, displaying human relations skills and delivering quality customer service. Similar to Hvass and Torfadóttir (2014), flight crew (due to their limited passenger interaction) and ground staff (outsourced) were not included in the study. 
Data collection involved two phases. For one week prior to and one week following CBT, 1,200 questionnaires were distributed in-flight to passengers. Selected flights were representative of all the carriers' routes to the Caribbean and North America and 109 flight attendants were assessed on flights before and after CBT. Prior to the distribution of questionnaires, the purser (lead flight attendant) made an announcement with instructions. Passengers were informed that participation was voluntary, that their information would be anonymous, confidential and used only to bench mark their data against other respondents. The questionnaire took approximately 10-15 minutes to be completed and no incentives were offered for participation. Following the announcement, flight attendants randomly distributed the selfadministered questionnaires and prior to descent, all surveys (used and unused) were collected. Pursers sealed all surveys in the envelope provided and submitted with the Flight Service Report (FSR). In total, 317 usable questionnaires were returned (of the 600 distributed), representing a $52.8 \%$ response rate (pre-CBT) and 463 usable questionnaires were returned (of 600 distributed) representing a $77 \%$ response rate (post-CBT). Pre- and post-training measures of flight attendant performance and customer satisfaction were taken using the same instrument.

The questionnaire consisted of three parts. In part one, respondents were asked to provide flight information, primary reason for travel, frequent flyer status among other information. Part two consisted of questions on flight attendants' grooming. For the third part, respondents were asked questions relating to flight attendant interaction and friendliness with passengers, flight attendant performance, level of satisfaction and behavioral intention. Demographic profiles were also established on questions of gender and age group. 


\section{Measures}

\section{Dependent Variables}

For the purpose of this study, two dependent variables were assessed using measurement items adapted for an airline setting. The first dependent variable, customer satisfaction, was measured by passengers' response to the statement, "Overall, how would you rate the level of customer service you received on this flight?" The four response options ranged from "very good" to "poor" (the "not applicable' category was omitted during data analysis due to the proportion of non-responses). For subsequent descriptive and bivariate analysis, the 4-point numeric scale measuring customer service was recoded into a 3-point numeric scale ('poor' and 'acceptable' coded as 1, while 'good' and 'very good' were coded 2 and 3, respectively). Therefore, the higher scores indicated higher levels of customer satisfaction.

The second dependent variable, flight attendants' performance, was measured using eight items adapted from the determinants of service quality (Parasuraman, Zeithaml, \& Berry, 1985): courtesy, efficiency, attentiveness, providing information, resolving problems, teamwork, presence throughout flight, timing of the meal service, were measured by passengers' responses to a 3-point scale ranging from "exceeded expectation" to "below expectation" ("no expectation' and 'not applicable' categories were omitted prior to data analysis due to the proportion of nonresponses). All scale items were summed to create a single variable $(\alpha=0.95)$ ranging from 0 16. Therefore, higher scores indicated higher levels of flight attendants' performance.

\section{Independent Variable}

CBT status was measured as a dummy variable with a value of 0 for pre-CBT and a value of 1 for the post-CBT. 
Missing values. For both dependent and independent variables response categories "no expectations" and "not applicable" have been declared missing for analysis purposes due to the high proportion of non-responses.

\section{Procedure}

The National Vocational Qualification (NVQ) Framework is recognized nationally, in the Caribbean Community and Common Market (CARICOM) and in some Commonwealth countries. Within the NVQ Framework, learners are assessed by a certified assessor from the National Training Agency against standard criteria or benchmarks and are certified competent when they are able to demonstrate the necessary knowledge, skills, understanding, and attitude to successfully perform his/her tasks in accordance with the workplace requirements. Competency standards which are the basis on which performance is evaluated, are developed and validated by industry-lead groups and in accordance with standards benchmarked internationally. The NVQ certification is awarded at five levels:

Level 1: Directly Supervised Worker

Level 2: Supervised Skilled Worker

Level 3: Independent/Autonomous Skilled Worker

Level 4: Supervisory/Specialist Worker

Level 5: Managerial and/ or Professional Worker

Training schedule. For three consecutive weeks, 31 pursers (lead flight attendants) participated in a two-day leadership workshop geared towards competency development. Similarly, for seven consecutive weeks, 78 flight attendants also participated in a two-day leadership workshop geared towards competency development. Using well-defined, objective criteria, a total of 109 flight attendants (including pursers) were trained, assessed and certified in 
the art of delivering quality service while dealing with conflicting and stressful situations. Additionally, building the intellectual capacity and skills of flight attendants in customer service skills was deemed a requisite tool for the airlines' continued success. Therefore, four Business Administration Level 2 units from the NVQ Competency Standard were selected:

1. Manage stress;

2. Deal with conflict situations;

3. Display human relation skills;

4. Deliver quality customer service.

Pre-CBT. Prior to CBT of all flight attendants, customer satisfaction questionnaires were administered to passengers traveling between the Caribbean and North America. Random sampling was employed to administer questionnaires to passengers in-flight by pursers and flight attendants all of whom had not yet participated in the training.

Prior to training, flight attendants received learner guides for each unit, which was designed to guide them through a series of learning processes and activities. The self-paced guide helped the flight attendants accomplish specified learning outcomes for the competency unit. Each participant was also required to successfully complete two written assessments achieving a pass mark of $70 \%$ or more.

During the workshop. A variety of training methodology and equipment were utilized to successfully train and assess the flight attendants. All training sessions were interactive and cabin crew instructors used a combination of guest lecturers, videos, role plays, team activities and oral presentation. Training equipment required to conduct aspects of the CBT and assessment included, simulated aircraft and check-in setup, sample boarding pass and airline safety equipment. To determine mastery of the performance criteria, on the second day of each 
workshop an assessment comprising of two components were conducted: an external written assessment as well as a practical assessment (simulated job site practical and role play). The duration of the assessment was approximately three hours. Assessments could take longer than the scheduled time as this was directly dependent on the speed at which the flight attendant was able to demonstrate the level of competency in the required areas to the external assessors. All 109 flight attendants successfully completed CBT and were awarded a Statement of Competency from the NTA in the units in which they were deemed competent by the external assessors.

Post-CBT. Following the CBT of all flight attendants, customer satisfaction questionnaires were again administered to passengers flying between the Caribbean and North America. Random sampling was also employed to administer post training questionnaires to passengers in-flight. All flight attendants on the surveyed flights had completed CBT. Subsequently, the questionnaires were examined for whether improvements had been made in the overall employee performance and customer satisfaction. The results have been summarized in the following section.

\section{Results}

\section{Descriptive Analysis}

Table 1 represents descriptive statistics for passengers who completed questionnaires preand post-CBT. Approximately seven in ten passengers were females who completed precompetency training survey. The modal age group of passengers was $35-44$ years (41\%) followed by 55 years (27\%). More than $90 \%$ of passengers who answered the pre-competency based training survey sat in economy class and almost $43 \%$ of passengers reported that vacation was the reason for travel. Almost one fifth (18\%) of all passengers were members of the 
airline's frequent flier loyalty program. The mean scores for flight attendants' performance and customer service were 9.28 and 2.48 , respectively.

The characteristics of passengers who completed questionnaires based on post-CBT survey were similar to passengers who completed surveys based on pre-CBT. Approximately three-quarters of passengers were females and the modal age group category of passengers was $35-44$ years $(38 \%)$. Slightly more than one in ten (13\%) passengers sat in the business class. The majority of passengers' reason for travel was vacation. Airline loyalty membership accounted for $15 \%$ of passengers. The mean scores for flight attendants' performance and customer service were 9.32 and 2.68 , respectively. 
Table 1

\begin{tabular}{lcc}
\multicolumn{3}{l}{ Characteristics of Passengers Pre-and Post-CBT Surveys } \\
\hline & $\begin{array}{c}\text { Pre-CBT } \\
(N=317)\end{array}$ & $\begin{array}{c}\text { Post-CBT } \\
(N=463)\end{array}$ \\
& $\mathrm{M} / \%$ & $\mathrm{M} / \%$ \\
Characteristics & & \\
Gender & 31.5 & 25.7 \\
$\quad$ Male & 68.5 & 74.3 \\
Female & & \\
Age Group (Years) & 6.0 & 5.4 \\
18-24 & 18.6 & 18.4 \\
25-34 & 41.0 & 38.0 \\
35-44 & 7.9 & 14.9 \\
45-54 & 26.5 & 23.3 \\
55 and older & & \\
Seating Assignment & 7.3 & 13.2 \\
Business & 92.7 & 86.8 \\
Economy & & \\
Reasons for Travel & 43.2 & 53.8 \\
$\quad$ Vacation & 1.3 & 3.5 \\
Honeymoon/wedding & 11.7 & 6.3 \\
Business & 31.2 & 31.3 \\
Visiting friends/family & 12.6 & 5.2 \\
Other & 18.3 & 14.9 \\
Airline Loyalty Program & 81.7 & 85.1 \\
Yes & $9.28(0-16)$ & $9.32(0-16)$ \\
No & $2.48(0-3)$ & $2.68(0-3)$ \\
Flight Attendants' Performance & & \\
Customer Service & & \\
\hline
\end{tabular}

Bivariate analyses. Pearson's correlation analysis was conducted to test the first two hypothesis. In Table 2, Hypothesis One, which is based on results of passengers who completed questionnaires pre-CBT, is supported. There is a relationship between flight attendants' performance and customer satisfaction $(r=0.234, p$-value $=0.000)$. Similarly, the post-CBT results also indicated that the relationship between flight attendants' performance and customer satisfaction was significant $(r=0.250, p$-value $=0.000)$. Therefore, $\mathrm{H}_{2}$ is supported. 
Table 2

Correlations between Flight Attendants' Performance and Customer Satisfaction Scores

Pre-CBT Post-CBT

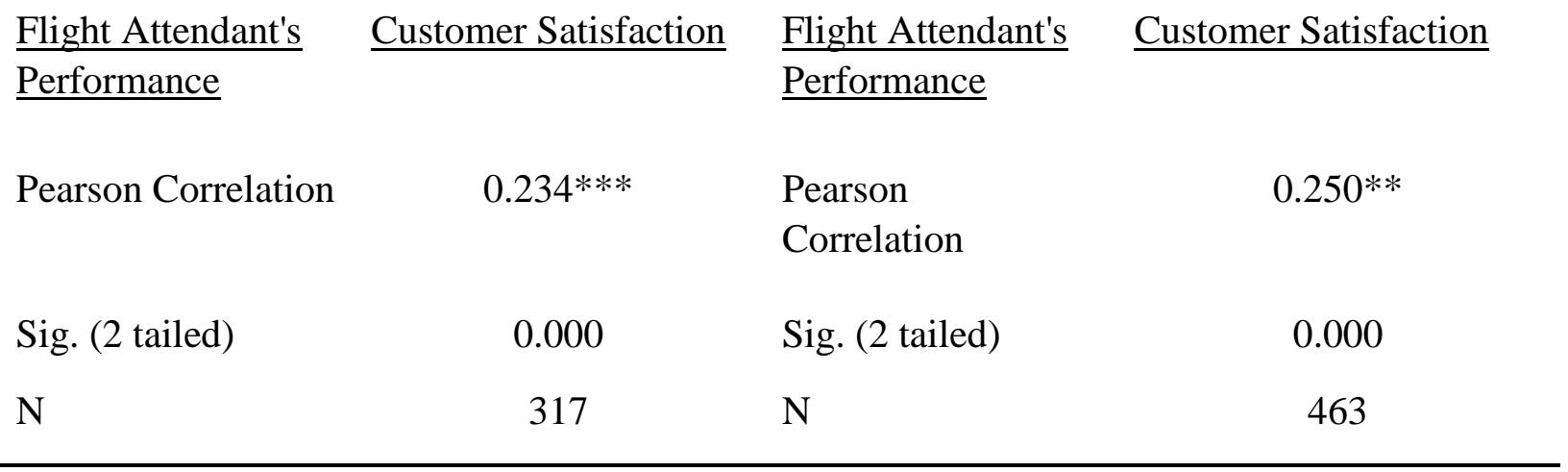

Hypotheses 3 and 4 used independent sample t-tests. Results from Table 3 indicated that flight attendants' performance mean scores were higher post-CBT (9.32) compared to pre-CBT (9.28). Based on equal variances assumed, the results indicated that flight attendants' scores were not statistically different when competency-based training is considered. Therefore, Hypothesis Three was not supported. The result for Hypothesis Four (Table 4) illustrated that the mean customer satisfaction score was higher post-CBT (2.68) compared to pre-CBT (2.48). Additionally, when equal variances were assumed, the findings showed that the mean customer satisfaction score was statistically significant when competency-based training was considered. This finding supports Hypothesis Four and suggest that the difference in customer satisfaction scores is associated with competency-based training intervention. 
Table 3

Independent Samples T-Test: Flight Attendants' Performance Scores and CBT

Group Statistics

Variable

$\begin{array}{lrl}N & \text { Mean } & \begin{array}{l}\text { Std. } \\ \text { Dev. }\end{array} \\ 317 & 9.28 & 2.68 \\ 463 & 9.32 & 2.75\end{array}$

Pre-Competency Based

Training

Post-Competency Based

Training

$\underline{\text { Independent Samples Test }}$

\begin{tabular}{lllllll} 
& Variable & $F$ & Sig. & $t$ & $\begin{array}{l}\text { Sig. (2- } \\
\text { tailed) }\end{array}$ & $\begin{array}{l}\text { Std. Error } \\
\text { Difference }\end{array}$ \\
& $\begin{array}{l}\text { Flight } \\
\text { Attendants' }\end{array}$ & & & & & \\
Equal variances assumed & Performance & .440 & .507 & -.196 & 0.844 & 0.198 \\
Equal variances not assumed & & & & -.197 & 0.844 & 0.197 \\
\hline
\end{tabular}

Table 4

Independent Samples T-Test: Customer Satisfaction Scores and CBT

Group Statistics

Variable

Pre-Competency Based

Training

Post-Competency Based

Training

$\underline{\text { Independent Samples Test }}$

Equal variances not assumed
Std.

$N \quad$ Mean Dev.

$317 \quad 2.48 \quad .68$

$\begin{array}{lll}463 & 2.68 \quad .67\end{array}$

\begin{tabular}{lllllll} 
& & & & & Sig. (2- & Std. Error \\
& $\begin{array}{l}\text { Variable } \\
\text { Customer }\end{array}$ & $F$ & Sig. & $t$ & tailed) & Difference \\
Equal variances assumed & Satisfaction & \multirow{2}{*}{1.515} & .219 & -2.97 & 0.003 & 0.049 \\
Equal variances not assumed & & & & -2.96 & 0.003 & 0.049 \\
\hline
\end{tabular}

\section{Contributions, Limitations and Future Research}

This paper contributes to the literature on CBT in aviation and to the best of our knowledge is the first study to investigate the effects of CBT on flight attendants' performance and consequently customer satisfaction. ICAO (2014) and IATA (2015) have developed and 
advocated for competency-based training approaches for aviation professionals from a safety and security perspective. We advocate for the inclusion of $\mathrm{CBT}$ as a standardized framework in flight attendant service training to increase on-the-job performance, service proficiency, employability skills and to appropriately balance cabin service with safety-related duties which ultimately leads to passenger satisfaction. Researchers also agree that satisfaction is a predecessor of increased market share, profitability, positive behavioral intentions and loyalty (Anderson, Fornell, \& Lehmann, 1994; Liao \& Chuang, 2004). Although factors such as price, flight schedules and loyalty influence passenger airline choice, the most important principle for competitiveness and survival among airlines, is delivering high-quality service along with safety and security to passengers.

Flight attendants face a myriad of challenges as they serve the traveling public. For example, they have to deal with stressful situations, manage conflicts and find resolutions, allay the fears of travelers while maintaining safety, security, and delivering high-quality service. Of practical significance for flight attendants', CBT is to ensure that whether cabin crews encounter a special need (such as expectant mothers, unaccompanied minors, incapacitated passengers, or the elderly) or a disruptive passenger, they have acquired the necessary knowledge, skills and attitudes and are competent to effectively handle each situation. Frontline service employees like flight attendants create a critical impression of the service by their behaviors and attitudes, which can significantly affect customer perceptions and satisfaction. Even though bivariate analysis revealed that flight attendants' performance scores were not statistically different, we suggest that the increase of scores is indicative of passengers receiving higher quality service.

Similarly, following CBT, customer satisfaction scores increased and this finding was statistically significant. We suggest that increased customer satisfaction scores may accrue 
several benefits to the airline namely: (1) positive word of mouth, (2) reputation that depicts a service-oriented airline, (3) increased trust in brand loyalty. We acknowledge that challenges exist when trying to ascertain if training programs are worth the financial investments especially in the case of non-significant findings. Kraiger, Ford, and Salas (1993) argued that training evaluations primarily determined whether training objectives were accomplished (learning issues) and if attaining the stated objectives resulted in improved job performance (transfer issues). While the relationship between flight attendants' performance and CBT status was not statistically significant, based on the increase in performance and customer satisfaction scores, we may infer that training and learning objectives were accomplished based on cognitive, affective or skill changes (Kraiger et al., 1993).

The findings from this study show that flight attendant CBT is effective in improving passenger satisfaction with in-flight service. However, the improvements reported in the study, although statistically significant, may be viewed as marginal by training managers. So we understand the reluctance of some organizations to invest significant sums into their training budget. Nevertheless, though the increase may not be large, the airline industry is so competitive that even minor improvements may give a differential advantage. Take, for example, rate of consumer complaints. Research (ICAO, 2003) indicates that among flight attendants considered to have poor attitudes, tension between their roles as service provider and safety compliance enforcer, was a primary reason for increased complaints from passenger (dissatisfaction).

The practical contribution of this study is twofold. Firstly, all 109 flight attendants successfully completed CBT and as a result were awarded a Statement of Competency - an internationally-recognized qualification, from the NTA in the units in which they were deemed competent by the external assessors. This training methodology supports the acquisition of skills 
and knowledge in a way that enables the learner to apply what they learn, in the work environment as well as to gain critical employability skills. Secondly, Damos et al. (2013), investigated the potential conflict between the performance of safety and security duties compared to completing airline-specified passenger service. Data was collected on flights from a major U.S. airline. The findings of that study showed that flight attendants were unable to complete the safety and security duties as required while achieving the airline-specified service standards. The researchers also observed that in some instances the flight attendants were unsuccessful in completing all safety, security and service duties appropriately. They recommended the exploration of other methods to ensure completing passenger service duties. This study provides empirical contributions for the inclusion of CBT flight attendant service training as a standardized framework to increase on-the-job performance, service proficiency, employability skills and to appropriately balance cabin service with safety-related duties.

The overall findings of this study support the notion that there was an association between flight attendant performance and customer satisfaction and that customer satisfaction was associated with CBT. The results show that even though there was a non-significant finding for flight attendant performance mean scores and CBT status, descriptive findings highlight higher mean scores for performance post-CBT relative to pre-CBT. Due to the nature of this research, the use of independent samples $t$-test to capture changes in the mean scores for customer service and flight attendants' performance by CBT was most appropriate. Future research will require a revised questionnaire in order to capture other variables that may impact flight attendants' performance (e.g. frequency of travel) and more rigorous multivariate techniques (Multiple Regression Analysis) will be employed to improve the findings. 
This study has a few limitations. Data collected was based on one airline, as a result the observations may not be representative of all airlines. Also, the study was limited by the short length of time between pre and post data collection. A longitudinal study may enhance the generalizability of these results. Additionally, external factors that may contribute to customer satisfaction and flight attendants' performance were not considered (e.g. age, gender, on-time performance, flight on schedule, check in process) for this study. The customer satisfaction and flight attendant performance were assessed on the most recent flight experience and may have influenced the results. The four competencies used in this study are units from the NVQ Competency Standard in Business Administration and not specific to aviation, this may have impacted the research. A CBT course is deemed effective by the method used to ascertain the core competencies necessary for a specific training.

Finally, the findings from this study came from passengers whose primary purpose for travel was vacation. Further, the findings of this research are akin to other studies that highlight how service quality is reflected in a customer's overall impression (Chen \& $\mathrm{Hu}, 2013)$. Since service quality is a key differentiator and provides competitive advantage, airlines should implement the necessary steps to exceed customer expectations. In conclusion, the most important principle for survival in this competitive industry is the delivery of the highest standard of service. Where an airline may be able to match prices, offer similar meal choices or schedule flexibility as its competitors, it is the delivery of high-quality service that stands out. 


\section{References}

Aguinis, H., \& Kraiger, K. (2009). Benefits of training and development for individuals and teams, organizations, and society. Annual Review of Psychology, 60, 451-474. https://doi.org/10.1146/annurev.psych.60.110707.163505

American Customer Satisfaction Index (ACSI). (2012). Customer satisfaction improves for airlines and fast food; sit-down restaurants and consumer shipping services drop. Retrieved from https://www.theacsi.org/news-and-resources/customer-satisfactionreports/report-archive/acsi-commentary-june-2012

Anderson, E. W., Fornell, C., \& Lehmann, D. R. (1994, July). Customer satisfaction, market share, and profitability: Findings from Sweden. Journal of Marketing 58(3), 53-66. https://doi.org/10.2307/1252310

Appelbaum, S. H., \& Fewster, B. M. (2004). Safety and customer service: Contemporary practices in diversity, organizational development and training and development in the global civil aviation industry. Management Research News, 27(10), 1-26. https://doi.org/10.1108/01409170410784301

Archana, R., \& Subha, M. V. (2012, February). A study on service quality and passenger satisfaction on Indian airlines. Zenith International Journal of Multidisciplinary Research, 2(2), 50-63. Retrieved from http://www.prosperfinancialmanagement.com/assets/client_files/PDFs/jd.pdf

Babbar, S., \& Koufteros, X. (2008). The human element in airline service quality: Contact personnel and the customer. International Journal of Operations \& Production Management, 28(9), 804-830. https://doi.org/10.1108/01443570810895267 
Bartel, A. P. (1994, October). Productivity gains from the implementation of employee training programs. Industrial Relations: A Journal of Economy and Society, 33(4), 411-425. https://doi.org/10.1111/j.1468-232X.1994.tb00349.x

Batt, R. (1999). Work organization, technology, and performance in customer service and sales. Industrial and Labor Relations Review, 52(4), 539-564 https://doi.org/10.1177/001979399905200403

Berry, L. L. (1999). Discovering the Soul of Service: The Nine Drivers of Sustainable Business Success. New York, NY: Free Press.

Bowen, B. D., \& Headley, D. E. (2016). Airline quality rating 2016: The $26^{\text {th }}$ year reporting airline performance. Retrieved from http://commons.erau.edu/cgi/viewcontent.cgi?article=1026\&context=aqrr

Boyatzis, R. (1982). The Competent Manager: A Model for Effective Performance. New York, NY: Wiley.

Chen, P.-T., \& Hu, H.-H. (2013). The mediating role of relational benefit between service quality and customer loyalty in airline industry. Total Quality Management \& Business Excellence, 24(9-10), 1084-1095. https://doi.org/10.1080/14783363.2012.661130

Curtis, T., Rhoades, D. L., \& Waguespack, B. P., Jr. (2012). Satisfaction with airline service quality: Familiarity breeds contempt. International Journal of Aviation Management, 1(4). https://doi.org/10.1504/IJAM.2012.050472

Damos, D. L., Boyett, K. S., \& Gibbs, P. (2013). Safety versus passenger service: The flight attendants' dilemma. The International Journal of Aviation Psychology, 23(2), 91-112. https://doi.org/10.1080/10508414.2013.772822 
Dolnicar, S., Grabler, K., Grün, B., \& Kulnig, A. (2011). Key drivers of airline loyalty. Tourism Management, 32(5), 1020-1026. https://doi.org/10.1016/j.tourman.2010.08.014

Fornell, C., Morgeson, F. V., III, \& Hult, G. T. M. (2016, September). Stock returns on customer satisfaction do beat the market: Gauging the effect of a marketing intangible. Journal of Marketing, 80(5), 92-107. https://doi.org/10.1509/jm.15.0229

Foyster, J. (1990). Getting to Grips with Competency-Based Training and Assessment. TAFE National Centre for Research and Development, Leabrook: Australia.

Heskett, J. L., Jones, T. O., Loveman, G. W., Sasser, W. E., Jr., \& Schlesinger, L. A. (1994). Putting the service-profit chain to work. Harvard Business Review, 105-11.

Hochschild, A. R. (1983). The Managed Heart: Commercialization of Human Feeling. Berkeley, CA: University of California Press.

Hvass, K. A., \& Torfadóttir, E. (2014, January). Spatially dispersed employee recovery: An airline case study. Journal of Air Transport Management 34, 65-69. https://doi.org/10.1016/j.jairtraman.2013.08.003

Hyland, T. (1994). Competence, Education and NVQs- Dissenting Perspectives. Cassell: London.

International Air Transport Association (IATA). (2015). Guidance material and best practices for MPL implementation. Retrieved from http://www.iata.org/whatwedo/ops-infra/traininglicensing/Documents/guidance-material-and-best-practices-for-mpl-implementation.pdf International Civil Aviation Organization (ICAO). (2003). Human Factors Digest No. 15 Human factors in cabin safety. Circular 300. 
International Civil Aviation Organization (ICAO). (2010). Next generation of aviation professionals - training and qualifications of aviation personnel. Retrieved from http://www.icao.int/Meetings/AMC/Assembly37/Working\%20Papers\%20by\%20Number /wp110_en.pdf

International Civil Aviation Organization (ICAO). (2014). Cabin crew safety training manual. Doc 10002.

Jackson, N. S. (1994). If competence is the answer, what is the question? A collection of readings related to competency-based training. Deakin University: Geelong, Australia.

Kearns, S. K., Mavin, T. J., \& Hodge, S. (2016). Competency-Based Education in Aviation: Exploring Alternate Training Pathways. Routledge Publishing.

Kim, Y., \& Park, H. (2014). An Investigation of the competencies required of airline cabin crew members: The case of a Korean airline. Journal of Human Resources in Hospitality \& Tourism, 13(1), 34-62. https://doi.org/10.1080/15332845.2013.807393

Klendauer, R., Berkovich, M., Gelvin, R., Leimeister, J. M., \& Krcmar, H. (2012, November). Towards a competency model for requirements analysts. Information Systems Journal, 22(6), 475-503. https://doi.org/10.1111/j.1365-2575.2011.00395.x

Kosbab, D. J. (2003). Dispositional and maturational development through competency-based training. Education and Training, 45(8/9), 526-541. https://doi.org/10.1108/00400910310508919

Kraiger, K., Ford, J. K., \& Salas, E. (1993, April). Application of cognitive, skill-based, and affective theories of learning outcomes to new methods of training evaluation. Journal of Applied Psychology, 78(2), 311-328. https://doi.org/10.1037/0021-9010.78.2.311 
Liao, H., \& Chuang, A. (2004). A multilevel investigation of factors influencing employee service performance and customer outcomes. Academy of Management Journal, 47(1), 41-58. https://doi.org/10.2307/20159559

Park, J.-W. (2007, July). Passenger perceptions of service quality: Korean and Australian case studies. Journal of Air Transport Management, 13(4), 238-242. https://doi.org/10.1016/j.jairtraman.2007.04.002

Park, J.-W., Robertson, R., \& Wu, C.-L. (2004, November). The effect of airline service quality on passengers' behavioural intentions: A Korean case study. Journal of Air Transport Management, 10(6), 435-439. https://doi.org/10.1016/j.jairtraman.2004.06.001

Parasuraman, A., Zeithaml, V. A., \& Berry, L. L. (1985, Autumn). A conceptual model of service quality and its implications for future research. Journal of Marketing, 49(4), 4150. https://doi.org/10.2307/1251430

Robotham, D. (2003). Learning and training: Developing the competent learner. Journal of European Industrial Training, 27(9), 473-480. https://doi.org/10.1108/03090590310506487

Saha, G. C., \& Theingi. (2009). Service quality, satisfaction, and behavioural intentions: A study of low-cost airline carriers in Thailand. Managing Service Quality: An International Journal, 19(3), 350-372. https://doi.org/10.1108/09604520910955348

United Nations World Tourism Organization (UNWTO). (2017, January 17). Sustained growth in international tourism despite challenges [Press release]. Retrieved from www2.unwto.org/press-release/2017-01-17/sustained-growth-international-tourismdespite-challenges 
Wu, J.-L. (2013). The study of competency-based training and strategies in the public sector: Experience from Taiwan. Public Personnel Management, 42(2), 259-271. https://doi.org/10.1177/0091026013487124

Zeithaml, V. A., Berry, L. L., \& Parasuraman, A. (1996). The behavioral consequences of service quality. Journal of Marketing, 60(2), 31-46. https://doi.org/10.2307/1251929 